\title{
AFHVS 2021 Presidential Address: critical praxis and the social imaginary for food systems transformation
}

\author{
Kim L. Niewolny ${ }^{1}$ (1) \\ Accepted: 8 October 2021 / Published online: 1 November 2021 \\ (c) The Author(s), under exclusive licence to Springer Nature B.V. 2021
}

\begin{abstract}
In this 2021 AFHVS Presidential Address, Kim Niewolny provides a brief foray into the onto-epistemic framing of critical praxis for sustainable food systems transformation. Niewolny proposes we engage in the creative entanglement of critical praxis and the social imaginary to "unthink" the orthodoxies that govern our ideas of the possible. She offers several possibilities as pathways toward a food system that embodies health equity, ecological justice, land sovereignty, and human rights, including: (1) agroecological research and movement building; (2) food, farm, and health policy; (3) food and farm system worker protections as public health and human rights concerns; (4) intersectional food justice scholarship and curriculum; (5) narrative-led, community-based, and action-oriented methodologies as multi-dimensional inquiry; (6) and multi-sector and multi-racial coalitions as dynamic networks that challenge linear, neoliberal, and technical-rational practices. Niewolny concludes with a call for radical hope as a principle for critical food systems praxis.
\end{abstract}

Keywords Critical praxis · Ontological politics $\cdot$ Social imaginary $\cdot$ Sustainable food systems

Reflecting on the past year feels a little like leaving the house for the first time in months. There is so much to say and do, it is difficult to settle on the right words or the correct course of action. Much of what I aim to share in this essay has been stewing in several places as I fix my gaze on the possibilities of critical praxis and the social imaginary for food systems transformation. Some of which has been the basis of ongoing conversations with colleagues, exchanges with students, collaborations with community partners, and new white papers and community-based projects through our Virginia Tech Center for Food Systems and Community Transformation. Some thoughts have also taken root while finding respite in my home garden and kitchen. It is certainly noteworthy that my ability to shelter in place with my family, continue to work, albeit with disruption and disorder, yet in relative safety and stability, is a privilege I have. With that said, I am grateful for those whose land, labor, and wisdom have and continue to provide life-giving sustenance in the most challenging of times.

Kim L. Niewolny

niewolny@vt.edu

1 Virginia Tech, 282 Litton-Reaves Hall (0343), Blacksburg, VA 24061, USA
I am also inspired by the collective hopefulness and actions of change makers and frontline workers embedded in the work of community food and sustainable food systems. As noted by many others many times before, the structural and corporeal effects of our food system are profoundly troubling. The ways in which food movement actors perform in response to the globalizing forces that perpetuate food system un-sustainability serves as a rich seedbed for social critique and knowledge creation that not only informs our actions but also humanizes the everyday experiences of struggle and resistance.

There is hope for transformation in the global food system. Like others, I argue that our most paramount food system challenges require a different kind of social imagination-one that moves us beyond the dominant view of linear, neoliberal, and technical-rational perspectives and solutions. Instead, the scale and complexity of the current system necessitates new forms of scholarly praxis that gives rise to dynamic systems of knowing and action that embody an intersectional approach to health equity, ecological justice, land sovereignty, and human rights as our guiding imaginary for food justice. From an agroecological perspective, the food system cannot simply be excavated and isolated from other systems of power and privilege. To move in this direction, scholar-practitioners will require a 
more generative imaginary to better understand, resist, and dismantle the stronghold of neoliberal narratives, settler colonialism, white supremacy, ableism, patriarchal frames and actions, and hetero-gender-normativity in our everyday spaces of food system learning and action.

For me, the path forward is riddled with questions and possibilities. One such possibility rests on the legitimizing of reflexive, participatory, and dialogical modes, processes, and frameworks - as critical praxis- to engender social, cultural, and epistemic justice in the food system. This includes embracing food systems work as a heterogonous space of criticalness and generative possibility where the experiences of those most disrupted by food system inequities set research, program, and policy agendas through civil society networks and collaborations in their many forms and scales. It also means rethinking the orthodoxies that govern what kinds of knowledge is validated and reproduced in our food system scholarship. My aim in this essay is to provide a brief foray into this onto-epistemic framing of critical praxis for sustainable food systems transformation. Through this lens, I propose we engage in the creative entanglement of critical praxis and the social imaginary to cultivate the kind of food system change we seek.

Drawing upon this year's conference theme, we need to first situate the role of social justice in food systems praxis. In particular, the demand for food justice has rightly informed the direction and strategies of food system movements in recent years. The notion of food justice, however, does not necessarily prescribe clear routes to establish a more just food system; instead, it provides new ways of thinking about access, power, privilege, and equity that may open up pathways for collective action and ethical practice (Agyeman and Alkon 2011; Alkon and Guthman, 2017; Garth and Reese, 2020). As it relates to growing concerns for the sustainability our of food systems, we see how issues of power and privilege have been heightened to new levels of severity as the COVID-19 pandemic has deepened the gap of food access and availability injustice, adding to already severe levels of stress and anxiety. This moment continues to expose the disparities and underlying inequities across the global food system that resided long before with little to no accounting for environmental, social, and health equity. The current moment further reveals how legacies of structural oppression linger as the systematic exploitation of Brown and Black bodies continues (Jackson 2020). And let us not forget that the COVID-19 pandemic continues to be deeply unsettling. The effects are particularly devastating in low-wealth communities as Global North countries disproportionally acquire vaccines while Southern nations struggle to provide much needed health care. In these and many other ways, it is no wonder many of us are fraught with uncertainty, grief, anxiety and loss.
Yet there is strength and power in our collective struggle for hope and transformation.

It is heartening that we can look to one another for ways forward. I am encouraged by numerous critiques and calls for action emerging from our academic, policy, and grassroots spaces. For instance, a pandemic-informed report published by the International Panel of Experts (IPES) (2020) on sustainable food systems serves as a global reminder that that time for critical assessments of the current system is long overdue. We must act to ensure the most vulnerable are protected from the shocks in the system while building resiliency in our agri-food alternatives through democratic participation and multi-sector movement building. Taking this further, IPES-Food (2021) recently published, A Long Food Movement: Transforming the Food Systems by 2045an astute call to center biodiversity, agroecology, and human rights in our food, health, and agricultural policy and practice. We can also look to the journals for special collection of essays, most notably in Agriculture and Human Values during the onset of the pandemic from March-May 2020. I encourage the field to read this collection of essays and commentaries from over 120 scholars, authors, practitioners, farmers, activists, and analysts of agriculture and food systems from around the world. Additionally, we do not need to look much further than our own institutions, organizations, and communities through the collection of papers, panels, roundtables, creative works, and workshops that comprise the 2021 Joint Annual Conference of Agriculture, Food \& Human Values Society (AFHVS), Association for the Study of Food \& Society (ASFS), Canadian Association for Food Studies (CAFS), and Society for the Anthropology of Food $\&$ Nutrition (SAFN).

Taken further, we see the strength and resiliency of food system movement actors through direct collective action, community mobilization, and mutual aid initiatives from soil to plate. In particular, we witnessed alliances of farmers, universities, cooperative extension-led programs, and community-based organizations working together to keep communities fed with locally produced foods; to keep farmers engaged in planting and harvesting; to keep local businesses and organizations operational; and to serve pack-and-go meals to schoolchildren. We also saw how farmers markets, restaurants, and food hubs adapted food handling protocols, set up online markets, and organized curbside service.

So how might we address the current moment and future crises? As it relates to global concerns for racial justice, land sovereignty, and human dignity? As it relates to our collective survival as climate change emerges as the next wave of adversity and chaos. What have we learned-as scholars, educators, policy makers, and movement makers? Asked differently, what does a resilient and fair system actually look like and for whom? Methodologically, what strategies of resistance, disruption, and repair make sense? Ontologically, 
what worlds are being made through our praxis, and more importantly, how could they be done differently for just ends?

For me, the answers to some of these questions focuses less on what we know in our research, policy, and teaching spaces and more on how we create change by engaging in the politics of knowledge as praxis. Using a Freirean (1972) concept, I am encouraged by critical praxis. For some, the concept of critical praxis provides us with the means to create new possibilities in/from/with practice that is performed, theorized, reflected on, reimagined, and then reperformed as praxis takes new form. This includes recognizing how structural and agential power dynamically operates. This also rests on our ability to move away from simply theorizing "what is happening" in our food system; instead, critical praxis gives way to the explorations of performativity (Gibson-Graham 2006). That is to say, critical food systems praxis ought to be less technical and linear in form and function and more generative through world-making activity and possibilities (Law 2008). We might then ask: how might we ethically engage with the ontological productivity of our food systems work? I would like to see more balance in the academy between theorizing and critiquing the forces of change in our unjust food system with encouraging and rewarding community-based, action-oriented, and participatory approaches with frontline and civil society groups in our research and teaching. In this way, I am encouraged by interdisciplinary and networked-based scholarship and teaching approaches that embrace food systems work as more reflexive, emergent, and dialogical-that is, less extractive and distant from field to classroom.

Conceptually, I argue that critical praxis provides a valuable lens to help us navigate the epistemological and ontological conditions that inform possibilities for food system transformation. As an onto-epistemic project, our priorities could shift with a keener focus on the needs and concerns of those most vulnerable to the disruptions and inequities in the food system. In this way, it is crucial that those who most benefit from pervasive systems of privilege build solidarity with civil society groups who are actively creating pathways for land, food, and environmental justice through such frameworks as agroecology, food sovereignty, racial justice, and collective agency. This would require more than a shift in vision and imagination, however. Instead, it would comprise a restructuring of social commitments, social capital, and financial resources. It would especially require a redistribution of resources and decision-making power to communities most impacted by the hegemonic politics of food access and availability. Thus, the role of reflexivity in critical praxis is crucial. In other words, it is the task of food system scholar-practitioners to nurture a healthy skepticism and scrutiny of the knowledge cultures that govern our own positionalities and privileges in food system research and curriculum.

As scholars, teachers, and practitioners, there is much room to heighten the activities and platforms of food movements in new and familiar communities both near and far. Practically speaking, this may include but is not limited to partnering and uplifting: (1) engaged agroecological research and movement building, especially within landgrant universities as spaces of tension and possiblity; (2) food, farm, and health policy at the scale of local municipalities, regional councils, nation states, and international bodies; (3) the creation of food and farm system worker protections as public health and human rights concerns; (4) intersectional food justice scholarship and curriculum, (5) narrative-led, community-based, and action-orientated methods as multi-dimensional inquiry of human and natural systems; and (6) multi-sector and multi-racial coalitions as dynamic networks of knowledge sharing and governance that move us away from linear, neoliberal, and technicalrational "best practice" solutions.

As I have said before (see Niewolny, 2021), I am hopeful that the current moment helps us to create new conditions for the life-affirming possibilities we seek. To deliberately "unthink" the orthodoxies that govern our ideas of the possible-as critical praxis for food systems transformationis generative movement toward cultivating a new social imaginary that is more humane, compassionate, and just. According to Lather (1991), such efforts are "rooted in our ability to provide a change-enhancing context" that is further "grounded in respect to human capacity and, yet, profoundly skeptical of appearances and common sense" (p. 65). To that end, I conclude with a poem to feed our collective imaginations and appetite for change. I find it helpful to remember that this work emphasizes embodied experience. Share food with a friend. Listen to someone's story. Be willing to sit with the discomfort. Resist and disrupt in ways that uphold your humanity (Lear 2008). For food systems movement work in its many forms requires a kind of praxis that is far less transactional and mechanical; instead, it is lived and felt. I share A Litany for Survival by Audre Lorde (1978). May we all speak up:

For those of us who live at the shoreline

standing upon the constant edges of decision

crucial and alone

for those of us who cannot indulge

the passing dreams of choice

who love in doorways coming and going

in the hours between dawns

looking inward and outward

at once before and after

seeking a now that can breed

futures 
like bread in our children's mouths so their dreams will not reflect the death of ours; For those of us who were imprinted with fear like a faint line in the center of our foreheads learning to be afraid with our mother's milk for by this weapon this illusion of some safety to be found the heavy-footed hoped to silence us

For all of us this instant and this triumph We were never meant to survive. And when the sun rises we are afraid it might not remain when the sun sets we are afraid it might not rise in the morning when our stomachs are full we are afraid of indigestion when our stomachs are empty we are afraid we may never eat again when we are loved we are afraid love will vanish when we are alone we are afraid love will never return and when we speak we are afraid our words will not be heard nor welcomed but when we are silent we are still afraid

So it is better to speak remembering we were never meant to survive.

Funding n/a.

\section{Declarations}

Conflict of interest The author declares that they have no conflict of interest.

\section{References}

Agyeman, Julian, and Alison Hope Alkon. 2011. Cultivating food justice: Race, class, and sustainability. Cambridge: MIT Press.

Alkon, Alison Hope, and Julie Guthman. 2017. The new food activism: Opposition, cooperation, and collective action. Oakland: University of California Press.
Freire, Paulo. 1972. Pedagogy of the oppressed. New York: Continuum International Publishing Group.

Garth, Hannah, and Ashanté M. Reese, eds. 2020. Black food matters: Racial justice in the wake of food justice. Minneapolis: University of Minnesota Press.

Gibson-Graham, J.K. 2006. A postcapitalist politics. Minneapolis: University of Minnesota Press.

International Panel of Experts (IPES) on Sustainable Food Systems. 2020, April. COVID-19 and the crisis in food systems: Symptoms, causes, and potential solutions. IPES. http://www.ipes-food.org/ img/upload/files/COVID-19_CommuniqueEN.pdf (accessed February 5, 2021).

International Panel of Experts (IPES) on Sustainable Food Systems. 2021, March. A long food movement: Transforming food systems by 2045. IPES. www.ipes-food.org/_img/upload/files/LongF oodMovementEN.pdf (accessed June 10, 2021).

Jackson, Jannie. 2020, May 13. Our food system is very much modeled on plantation economics: CounterSpin interview with Ricardo Salvador on the coronavirus food crisis. 2021. https://fair.org/ home/our-food-system-is-very-much-modeled-on-plantationeconomics/ (accessed June 2, 2021).

Journal of Agriculture, Food, \& Human Values, Agriculture, Food \& Covid-19, ISSN: 0889-048X (Print) 1572-8366 (Online) https:// link.springer.com/journal/10460/topicalCollection/AC_f5a2c $2971 \mathrm{f} 8 \mathrm{e} 17 \mathrm{ca} 3 \mathrm{f} 5401 \mathrm{cfb} 405594 \mathrm{c} / \mathrm{page} / 3$.

Lather, Patti. 1991. Getting smart: Feminist research and pedagogy with/in the postmodern. London: Routledge.

Lear, Jonathon. 2008. Radical hope: Ethics in the face of cultural devastation. Cambridge: Harvard University Press.

Lorde, Audre. 1978. A litany for survival. The black unicorn: Poems. New York: Norton Press.

Law, John. 2008. On sociology and sts. The Sociological Review 56 (4): 623-649.

Niewolny, Kim. 2021. Boundary politics and the social imaginary for sustainable food systems. Journal of Agriculture, Food, \& Human Values 38: 621-624. https://doi.org/10.1007/s10460-021-10214-0.

Publisher's Note Springer Nature remains neutral with regard to jurisdictional claims in published maps and institutional affiliations.

Kim L. Niewolny is an associate professor in the Department of Agricultural, Leadership, and Community Education at Virginia Tech and serves as founding Director of the Virginia Tech Center for Food Systems and Community Transformation. Kim's work centers on the role of power and equity in community education and development with scholarly interests in ontological politics, action research; participatory and cultural community development; critical pedagogy; multi-sector collaborations for sustainable food systems; and the political praxis of community food work. Current initiatives emphasize Appalachian food justice; new agrarian sustainability; and the intersection of technology, farm workers, and disability. Kim also provides teaching leadership in the Civic Agriculture and Food Systems minor and serves as Director of the Virginia Beginning Farmer and Rancher Coalition and Director of AgrAbility Virginia. She currently serves as the Past President of the Agriculture, Food, and Human Values Society and has been a board member of the Virginia Food Systems Council since 2018. 